Izr. prof. $d r$.

Nives Ličen

Filozofska fakulteta

Univerze v Ljubljani

\title{
MODEL SKUPNOSTI PRAKSE IN SITUACIJSKO UČENJE
}

\section{POVZETEK}

Učenje v vsakdanjem življenju ali situacijsko učenje postaja vse pomembnejše. Razvijajo se modeli za interpretacijo in raziskovanje ter razvijanje prakse v povezavi z novejšimi koncepti znanja in učenja ter formiranja identitete. V prispevku analiziramo tezo, da situacijsko učenje kot neorganizirano učenje prehaja $v$ strukturirano učenje, zato je v prvem delu predstavljena razčlenitev situacijskega učenja in teoretskega ozadja za razvoj koncepta skupnosti prakse.

$V$ drugem delu avtorica komparativno predstavi dva modela učenja in situ, in sicer skupnosti prakse in akcijsko učenje kot modela, ki omogočata prenos znanja in razvoj inovacij. Oba modela se povezujeta s poststrukturalistično teorijo prakse in transformativnim učenjem. Podobnosti in razlike med njima kažejo prednosti in pomanjkljivosti za uporabo $v$ praksi in razvoj teorije situacijskega učenja.

Ključne besede: situacijsko učenje, praksa, delovalnost, skupnost prakse, akcijsko učenje

\section{COMMUNITY OF PRACTICE AND SITUATED LEARNING - ABSTRACT}

The importance of everyday life learning or situated learning is growing, and new models for interpretation and research are being developed in concordance with new knowledge concepts and theories of learning. The article brings an analysis of situated learning as a type of learning without a fixed structure which develops (transforms) into an organized and structured learning form. The first part examines the concept of situated learning and the theoretical context of the model of communities of practice. The second part presents a comparative analysis of two models of situated learning, action learning and the community of practice, as the forms which support transmission of information and knowledge and imply innovation development. Both models are rooted in the context of poststructuralist practice theory and transformative learning theories. Advantages and deficiencies of the analysed models direct the practical use of action learning or communities of practice.

Keywords: situated learning, practice, agency, community of practice, action learning

UDK : 374.7

\section{UVOD}

$\mathrm{V}$ teoriji in praksi izobraževanja odraslih $\mathrm{v}$ zadnjih 20 letih opažamo hitro dinamiko pojavljanja novosti v pogledih na učenje. Eden od vidnejših premikov je širitev raziskovanja od organiziranega učenja (oz. formalnega in neformalnega izobraževanja) $\mathrm{k}$ učenju $\mathrm{v}$ vsakdanjem življenju (situacijsko učenje). V povezavi s tem nastajajo razprave, ki preizprašujejo razmerja med koncepti vseživljenjskega učenja, nadaljnjega izobraževanja in neformalnega izobraževanja (Hager, Halliday, 2009) in tudi interdisciplinarnosti ter medgeneracijskosti (Wilson, 2010).
Druga pomembnejša nova smer raziskovanja in razvijanja prakse se kaže v dopolnjevanju konceptov prenosa znanja, ki je umeščeno $\mathrm{v}$ hierarhično določene odnose in diskurze, $s$ koncepti ustvarjanja znanja in oblikovanja identitete $\mathrm{v}$ različnih okoljih. Nastajajo nove teorije in modeli za interpretacijo učenja, kot npr. v delih avtorjev Engeström, Jarvis, Alheit, Baert (Illeris, 2010), ki so povezani z novejšimi koncepti znanja (Knorr-Cetina, 1999). Strokovnjaki se ne ukvarjajo le z diseminacijo že oblikovanega znanja, marveč tudi z ustvarjanjem znanja $\mathrm{v}$ različnih okoljih (doing knowledge) in vedno bolj intenzivno z razvojem ali formiranjem identitete. 
Naslednji premik vidimo v pojmovanju učenja kot sociokulturnega procesa, kar pomeni, da je učenje spreminjajoč se fenomen, ki je odvisen od kognitivnih, kreativnih in komunikacijskih dejavnikov v nekem sociokulturnem okolju. Pristopi, ki raziskujejo učenje kot del kulturnih praks, učenja ne pojmujejo več kot zgolj individualni kognitivni proces, $v$ katerem posameznik pridobiva informacije iz dekontekstualiziranega kompleksa znanja, temveč kot kontekstualni proces, v katerem nastaja eksplicitno in implicitno znanje. Za posameznikovo učenje je pomembna moč vsakdanje prakse, v kateri participira. Ti pogledi postavljajo v ospredje dejavnost posameznika pri oblikovanju praks. Teorije, ki interpretirajo učenje, upoštevajo raziskave s področja teorije delovanja (activity theory), in sicer s socioloških in filozofskih vidikov (prim. Engeström, 2010), ter razvijajo koncept učenja v organizaciji.

Vse to povečuje zanimanje za situacijsko učenje. Zanimanje ni naraslo le $\mathrm{v}$ pedagogiki in andragogiki, marveč tudi v družbenih vedah, komunikacijskih študijah in menedžmentu, saj daje teoretski okvir za razpravo o tem, kako se ljudje in organizacije učijo, da naredijo nekaj novega, in kako se posamezniki in organizacije spreminjajo. Ker je sodobna družba $\mathrm{v}$ nenehnem spreminjanju, moramo oblikovati take socialne sisteme, ki so prilagodljivi, ki se nenehno učijo in omogočajo posamezniku, da se nenehno uči. Sodobni koncepti refleksivne prakse vključujejo učenje kot prenos informacij in kot ustvarjanje novega znanja, ki je označeno s transmisijo in transgresijo. Ustvarjalnost je nujna, če naj ob novih problemih najdemo nove rešitve. Navadno ob ustvarjalnosti pomislimo na umetniške stvaritve ali na nove tehnološke dosežke, toda poleg teh postajata pomembni tudi socialna ustvarjalnost, s katero ljudje ustvarjajo nove odnose in družbene povezave, in identitetna ustvarjalnost pri oblikovanju sebstva.
Učenje, ki ni ločeno od vsakdanjega življenja in je del delovanja posameznika $\mathrm{v}$ dialogu $\mathrm{z}$ okoljem, imenujemo učenje v vsakdanjem življenju (learning in every day life) ali situacijsko učenje (situated learning). V nadaljevanju bomo uporabljali drugi izraz, upoštevajoč pogostost rabe. Situacijsko učenje bomo predstavili z analizo modela skupnosti prakse, ki obravnava učenje kot proces oblikovanja znanja in sebstva, učenje kot prakso in učenje kot ustvarjanje novega znanja ter s svojo strukturiranostjo nakazuje zgoraj omenjene premike $\mathrm{v}$ teoriji in praksi izobraževanja odraslih.

V prispevku raziskujemo značilnosti koncepta skupnosti prakse in se sprašujemo, kako prihaja do prehoda od situacijskega učenja (kot neorganiziranega, nenamernega učenja) k neformalnemu učenju (kot organiziranemu, rahlo strukturiranemu procesu učenja), kot se dogaja v praksi. Primerjali bomo skupnosti prakse in akcijsko učenje, da bi tako potrdili predpostavko, da skupnosti prakse lahko preidejo $\mathrm{v}$ akcijsko učenje ali pa se začne uporabljati strategija akcijskega učenja v povezavi z akcijskim raziskovanjem kot del svoje kulture in da tudi akcijsko učenje lahko preide $\mathrm{v}$ skupnost prakse.

\section{KONCEPT SKUPNOSTI PRAKSE}

Koncept skupnosti prakse (community of practice, comunità di pratiche), s katerim interpretiramo situacijsko učenje, je v izobraževalnih in organizacijskih vedah precejšnjo pozornost vzbudil že v 90. letih prejšnjega stoletja. Tema je bila zanimiva tako za raziskovalce (prim. Gherardi, Nicolini, 2004) kot tudi za praktike, še posebno potem, ko se je model, ki sta ga v začetku razvila antropologinja J. Lave in transdisciplinarni raziskovalec E. Wenger, povezal s konceptom organizacijske kulture, refleksivne prakse in akcijskega 
raziskovanja. V sodobnosti je najbolj poznan na področju upravljanja znanja (knowledge management) in izobraževanja odraslih.

Termin skupnosti prakse sta oblikovala J. Lave in E. Wenger leta 1991, ko sta razvijala koncepta situacijskega učenja in legitimne periferne participacije. Do tega poimenovanja sta prišla po opazovanju učenja v različnih skupinah v različnih kulturah (zdravljeni alkoholiki, mesarji, intendanti, krojači, babice). Ko sta odkrila način skupnega učenja kot pojav, ki ga opažamo v različnih skupnostih, sta - upoštevaje samoorganiziranost in neformalnost takega učenja - predlagala, naj okolje take skupine neguje, spodbuja. Ni pa jih treba namerno ustvarjati, ker nastanejo same, so samoporajajoče se sodelovalne skupine ob nekem delovanju in od tod tudi ime. Danes ga uporabljamo v različnih okoljih (v izobraževanju, podjetjih, virtualnih mrežah).

\section{Skupnosti prakse so povsod, so del vsakdanjega življenja.}

Skupnosti prakse so povsod, so del vsakdanjega življenja. Vsak posameznik se uči, ko participira $\mathrm{V}$ neki skupini. Učenje po tem modelu ni nekaj ločenega od delovanja; so le obdobja bolj ali manj intenzivnega učenja, toda učenje vedno poteka. Učenje je po njuni opredelitvi socialna praksa, v kateri se nenehno dogaja interakcija med socialno realnostjo in (re)konstrukcijo subjektivnosti.

Učenje je po tem modelu del vsake prakse. Po Wengerju in Lavovi (1991) se človek uči, ko participira v skupni praksi. Ker je učenje pojmovano kot način življenja, ne moremo - vsaj v tem modelu - ločiti učenja od dejavnosti. Ločimo lahko le bolj ali manj intenzivno učenje. Če bi poskusili razlikovati med učenjem in zabavo, najdemo razliko $\mathrm{v}$ tem, da je posledica učenja sprememba, bodisi na kvantitativni ravni (več ve, več zna) bodisi na kvalitativni ravni (spremenijo se vrednote, stališča, identiteta), vendar tudi zabava kot sociokulturna dejavnost vključuje učenje. Učenje je namreč po Wengerjevem modelu del človekove participacije v svetu in $\mathrm{s}$ tem del človekove narave, kot sta dihanje ali prehranjevanje.

Učenje je del vsake socialne participacije in posameznik je dejaven udeleženec v praksah. Participirati v igri na igrišču ali v delovni skupini - oboje pomeni neko dejavnost oz. obliko dejavnosti - hkrati pomeni tudi obliko pripadanja. Participacija ne določa le tega, kaj delamo, temveč tudi to, kako svoje delo/ dejavnost interpretiramo.

Komponente učenja po Wengerju (2006) so:

- praksa (učenje kot delovanje),

- pomen, smisel (učenje kot doživljanje sveta kot smiselnega),

- skupnost (učenje kot pripadanje; pomembna je socialna konfiguracija, v kateri je človekovo delovanje definirano in $\mathrm{v}$ kateri je participacija prepoznana kot kompetentna),

- $\quad$ identiteta (učenje kot postajanje; učenje spreminja življenjsko zgodovino/biografijo).

Te štiri komponente so medsebojno povezane in druga drugo določajo.

Situacijsko učenje v skupnostih prakse označuje učenje (pridobivanje in oblikovanje znanja ter razvoj identitete, pomenov in vrednot) v situacijah, kjer znanje tudi uporabljamo. Teorija situacijskega učenja se je oblikovala pod vplivom teorije učenja, ki jo je razvil Vigotsky, teorija skupnosti prakse pa pod vplivom teorije prakse P. Bourdieuja. Wenger je pri oblikovanju modela upošteval tudi 
dela Latoura, Orra, Wittgensteina, Goffmana (prim. Wenger, 2006: 21-22).

Skupnost prakse je model, ki opisuje procese učenja, vključujoč:

- delovalce (akterje), ki se zavzemajo za nekaj skupnega in jih povezujejo skupno področje, praksa in problemi;

- socialne odnose, ki se razvijajo po načelih skupnosti;

- kulturne značilnosti situacije, v kateri se oblikujejo pomeni, artefakti, načini uporabe materialov ipd.

Nastal je kot interpretativna shema, s katero pojasnjujemo učenje $\mathrm{v}$ nekem specifičnem okolju, kot je lokalno ali delovno okolje. Povezuje se s koncepti sodelovalnega učenja (collaborative learning) in tihega znanja (tacit knowledge) ter osebne izkušnje (subjective experience). Od drugih oblik izkustvenega učenja se razlikuje po štirih premisah, in sicer:

- učenje gnezdi v dejavnostih vsakdanjega življenja, je del vsakdanjih situacij,

- znanje nastaja $v$ situaciji in se prenaša $v$ podobne situacije, vsebine so inherentne delovanju v situaciji in nanje vplivajo vsi šumi, interakcije, zmeda ipd.,

- učenje je rezultat sociokulturnih procesov in vključuje zaznavanje problemov, način mišljenja in interakcij,

- $\quad$ učenje je del sistema akter \& aktivnost \& situacija.

Poudarjena sta učni potencial prakse (delovanja) in zmožnost ljudi, da se učijo, ko delujejo. Večinoma se svojega učenja niti ne zavedajo, tako da nastaja tiho znanje. Skupnosti prakse nastajajo in delujejo spontano. Ko pa se skupnosti prakse zavedo pomena svojega učenja in delovanja, tedaj postane temeljno načelo tudi namerno spodbujanje učenja in situ in vpeljevanje strategij učenja.

\section{Tiho znanje}

$\mathrm{Za}$ analizo učenja v skupnosti prakse sta pomembna koncept tihega znanja in koncept prakse, zato bomo najprej predstavili ta dva. Tiho znanje je raziskoval M. Polanyi v 50. letih prejšnjega stoletja (Polanyi, 1967; Polanyi, Sen, 2009), nato so koncept razvijali tudi drugi, npr. D. Schön v povezavi s konceptom refleksivne prakse, Nonaka in Takeuchi (1995) ter C. Linde (2009), ki tematizira naracijo kot most med tihim in eksplicitnim znanjem.

Tiho znanje se navadno razume kot komplementarno eksplicitnemu znanju. Je rezultat implicitnega učenja in implicitne refleksije, t.j. refleksije, ki poteka med delovanjem in se je navadno sploh ne zavedamo. Vključuje tudi predrefleksivno dimenzijo subjektivne izkušnje. Kot primere tihega znanja navajamo različne načine delovanja, npr. specifične načine dvigovanja vode, operiranja, kuhanja, pogovarjanja, načrtovanja hiš ... Tudi vrhunsko strokovno znanje, kot je denimo pediatrična operacija srca, vključuje tiho znanje, ki se ne prenese prek zapisanih virov. Tiho znanje so vse tiste oblike znanja, ki jih ne moremo kvantificirati, zato se ta vrsta znanja kaže kot posebej zahtevna za upravljanje. Načini delovanja so posledica utelešenega znanja (embodied knowledge), to so osebni konstrukti, ki so nastali kot konglomerat iz vseh vrst eksplicitnega in implicitnega učenja. Skupnosti prakse so pomembne prav za prenos tega tipa znanja, ki ga ne moremo ubesediti, ker se ga pogosto sploh ne zavedamo, saj v njem prevladuje predrefleksivna dimenzija.

Tiho znanje opazimo v praksi, ker je del rutin, prenaša se $\mathrm{v}$ socialnih mrežah $\mathrm{z}$ osebnim sodelovanjem. Primer, ki ga omenjajo raziskovalci tihega znanja, je konstruiranje stroja za domačo peko kruha. Kuharje v najboljših hotelih so opazovali, kako mesijo kruh, da so 
ugotovili, kakšni so njihovi gibi pri mesenju. Ko ljudje delujemo, navadno ne razmišljamo o načinih delovanja in mišljenja, temveč se osredotočimo na delovanje. Ko pisatelj piše svoj roman, ne razmišlja o tem, kako razmišlja, temveč razmišlja o zgodbi. Naša pozornost je usmerjena, a to ne pomeni, da se za te osredotočenostjo ne dogajajo kognitivni in emocionalni procesi. Bolj kot je posameznik strokovnjak na nekem področju, bolj je njegov način delovanja oseben, utelešen $v$ posamezniku, zato je težko prenosljiv s koncepti, ki jih uporabljamo pri prenosu eksplicitnega znanja. Težko je verbalizirati izkušnjo, zato je tiho znanje težko prenosljivo $\mathrm{z}$ abstraktnimi koncepti. Najpogosteje se prenaša s skupnim delovanjem in s pripovedovanjem zgodb. Slednje se nato $\mathrm{v}$ didaktičnih strategijah pri načrtovanem skupinskem učenju razvije v narativne metode.

Pomembna je ugotovitev, da se tiho znanje prenaša $v$ socialnih mrežah. Transfer tihega znanja zahteva osebni stik, zaupanje in razmeroma trajne interakcije, je v svojih delih ugotavljal Polanyi (2009). Natanko to je značilno za skupnosti prakse: osebni stik, razmeroma trajne interakcije, skupna praksa.

Tiho znanje ločimo od eksplicitnega po mehanizmih prenosa in kodificiranosti. Tiho znanje je neartikulirano, subjektivno, razpršeno, eksplicitno znanje je kodificirano, prenaša se v konceptih, tiho znanje se ohranja v zgodbah in veščinah, značilno je ustno izročilo.

Proces spreminjanja tihega znanja $\mathrm{v}$ eksplicitno je zato kodificiranje, artikuliranje, specificiranje, s čimer sta se za področje dela ukvarjala Nonaka in Tacheuci. Eksternalizacija tacitnega znanja je proces artikulacije tihega znanja $\mathrm{v}$ koncepte, ki jih lahko pre- našamo, in je tudi ozaveščanje rutin, kar se dogaja z ubeseditvijo. Ko proučujemo pripovedi o tihem znanju, ne smemo podleči epistemološki naivnosti, da bi verjeli, da je opis izkušnje (četudi zelo disciplinirano povedan) natančen odsev doživetega. Ni nujno, da pripoved natančno odseva izkušnjo. Težave pri raziskovanju povzroča tudi transformativnost pripovedi. Vsak moment eksplikacije uvaja transformacijo, zato je velik izziv prav metodologija raziskovanja.

\section{Teorija prakse}

Naslednja teorija, ki je ogrodje za interpretacijo učenja v skupnosti prakse, je teorija prakse. Praksa pomeni celoto koherentnih dejavnosti, ki so umeščene $\mathrm{v}$ kulturni kontekst ter se prenašajo z jezikom in načini delovanja.

Prakse opredeljujemo kot »telesne in mentalne rutine « (bodily and mental routines) (Reckewitz, 2002: 248), učenje pa pomeni »krizo prakse«, ker se z učenjem praksa spremeni. Nobena praksa ni hermetično zaprta v razmerju do drugih praks, vsaka prenese inovacije.

Reckwitz (prav tam) označuje prakso kot načine vedênja, ki so sestavljeni iz različnih medsebojno povezanih elementov. Ti elementi so: telesne in mentalne dejavnosti, artefakti in njih uporaba, znanje, čustva, motivacija. Primeri prakse pa so: načini kuhanja, dela, raziskovanja, skrbi zase in za druge. Prakse tvorijo vzorce, ki reproducirajo določene načine porabe ter ustvarjanja dobrin in odnosov. Praksa je kot preplet delovanja in izrekanja razumljiva delovalcem in tudi opazovalcem.

Poznamo več opredelitev prakse. MacIntyre (1981: 187) jo opisuje kot koherentno in kompleksno obliko socialno vzpostavljene človekove dejavnosti, pri kateri je ključno notranje 
dobro. To je nekaj, o čemer posameznik sodi, da bi dosegel ali da bi bil del nečesa. Kot tako vodi človeka $\mathrm{v}$ delovanje (acting). Wenger (2006) je to opredelitev modificiral. Prakso je opredelil kot koherentno in kompleksno obliko socialno vzpostavljene in umeščene dejavnosti, ki jo lahko poimenujemo z besedo ali frazo. Akterji prakso sistematično izboljšujejo (razvijajo). Pri tem se je ognil notranjemu dobremu kot opredeljevalcu prakse, upošteval pa je opredelitve sociologov in antropologov, ki so razvijali teorijo prakse.

Teorije prakse (practice theory), ki so vplivale na oblikovanje modelov situacijskega učenja, sestavljajo skupek teorij, ki se je razvil v tretji tretjini prejšnjega stoletja. Začetke iščemo v 70. letih, ko je Bourdieu leta 1972 objavil delo Outline of a Theory of Practice. Razvoj teorije prakse je povezan z zanimanjem za vsakdanjost in z avtorji, kot so Bourdieu, de Certeau, Foucault, Giddens, Latour, ki jih štejemo za avtorje prvega vala (Postill, 2010; Reckewitz, 2002).

Prva skupina teoretikov je iskala srednjo pot med individualizmom in holizmom, to je med trditvami, da je vsaka sprememba rezultat posameznikovega delovanja, in trditvami, da je možno vsak fenomen pojasnjevati z vplivi strukture oz. družbe kot celote. Ti avtorji so želeli poudariti delovalnost (agency), to je človekovo sposobnost, da deluje in spreminja svet, ter tako izstopiti iz omejitev strukturalističnih in sistemskih modelov.

$\mathrm{V}$ delih avtorjev prvega vala teorije prakse lahko opazimo človeško telo kot neksus človekovega praktičnega udejstvovanja v svetu, kar je za razumevanje učenja pomemben vidik, saj vodi $\mathrm{v}$ raziskovanje somatskega učenja. Večina teoretikov po zapisih Postilla (Postill, 2010) opredeljuje prakse kot področja dejavnosti (arrays of activity), v katerih je človeško telo neksus. To so torej zbirke dejavnosti, ki so povezane s človeškim telesom, telo je tisto, ki dejavnosti povezuje.

Bourdieu (2002) je razvil koncept habitusa, da bi ujel permanentno internalizacijo socialnega reda $v$ človeškem telesu ob priznavanju posameznikove zmožnosti za izumljanje novega. Slednje je osrednja točka v modelu učenja po Wengerju (2006: 23), ki postavi posameznika med napetosti strukturne določenosti in samouresničevanja ali avtopoiesisa.

Habitus producira strategije, ki so prilagojene situaciji, in oblikuje »permanentne dispozicije«. To so sheme zaznavanja in mišljenja, ki jih uporabljamo kot splošne teorije oz. pojme in nastajajo v vsakdanjem življenju bolj intenzivno kot $\mathrm{v}$ formalnem izobraževanju. Z življenjem v neki kulturi posameznik razvije predispozicije za delovanje na določene načine, kar je za modele situacijskega učenja pomemben vidik.

Bourdieu uporablja koncept polja (field). Polje je specialistično področje prakse (npr. fotografija) s svojo lastno »logiko«, ki se razvije iz kombinacije kapitalov (finančnega, simbolnega (prestiž, ugled), socialnega (omrežja)). Ta koncept je povzel Wenger pri opredeljevanju skupnega polja ali domene, ki jo ima skupnost prakse.

Znana metafora za polje je igra. Samo igralci z ustreznim »know howom « in verjetjem v igro bodo pripravljeni vlagati čas in napor $\mathrm{v}$ igranje igre. Vešči igralci sčasoma razvijejo občutek za igro ali praktični čut, ki jim dovoljuje, da improvizirajo na strukturiran način, ki navidezno učinkuje kot lahkotno, nenaporno delovanje. Strategije, ki jih razvije delovalec in ki se izkažejo za uspešne, delujejo kot racionalne in zavestne, toda $\mathrm{v}$ resnici, zapiše Bourdieu (2002), so mogoče, ker prihaja do 
dobre povezave med poljem in habitusom. $\mathrm{Na}$ to moramo biti pozorni pri opazovanju učenja v skupnostih prakse.

\section{Skupnosti prakse so neformalne skupine.}

Dejavnost, ki jo vodi praktični čut, ima vse značilnosti racionalne, načrtovane dejavnosti, kot jih lahko izlušči neudeleženi opazovalec. Vendar pa v resnici ni načrtovana, temveč nastaja na temelju impulzivnih odločitev. Primer takega delovanja je igra tenisa, kjer ni vidnega načrtnega preračunavanja, temveč le impulzivni odzivi.

Naslednji pomembni koncept je doksa. To so internalizirane domneve/predpostavke, splošno sprejeta prepričanja na nekem področju, o katerih se sploh ne sprašujemo. To so petrificirana prepričanja, ki omejijo razvoj novih strategij.

V drugo generacijo teoretikov prakse uvrščamo S. Ortner, ki je prav tako vplivala na Wengerjevo delo. Poleg nje sta pomembna avtorja tudi T. Schatzki in A. Reckewitz.

Če povzamemo različne opredelitve, ki so se odrazile v Wengerjevem delu, lahko ugotovimo, da so prakse pojmovane kot različne modalitete, ki so razmeroma stabilne in socialno prepoznavne po različnih elementih (osebe, znanje, predmeti, tehnologija). Prakse sestavljajo dejavnost, odnosi, kozmologije in jih (re)producirajo ljudje (delovalci).

\section{Prve empirične raziskave pri oblikovanju modela skupnosti prakse}

Skupnosti prakse so neformalne skupine, večina jih nima niti imena. Wenger (2006) opredeli skupnost prakse kot skupino ljudi, ki so v medsebojni interakciji, imajo skupno polje delovanja ali se zavzemajo za nekaj skupnega ter poglabljajo svoje razumevanje in znanje na tem področju, da bi prakso izboljšali.

Večina raziskav učenja v skupnostih prakse je opazovala socializacijo v poklicu, vstop novincev $\mathrm{v}$ poklicno prakso ali pa delovanje $\mathrm{v}$ profesionalnem okolju. J. Lave je proučevala učenje krojačev v Liberiji, babic na Jukatanu, J. Orr (1996) je proučeval delovanje tehnikov, ki so popravljali fotokopirne stroje $\mathrm{v}$ ZDA.

Skupnost prakse je v prvih raziskavah opredeljena kot forma socialnosti in socializacijska forma, oblikovana s prakso. Vključuje dve skupini, in sicer:

(a) posameznike, ki delujejo $\mathrm{v}$ organizaciji, skupaj opravljajo neko dejavnost, imajo skupno prakso, in

(b) posameznike, ki se vključujejo v delo. Tej delitvi sledijo prve raziskave učenja, kjer novinci vstopajo $\mathrm{v}$ polje dela in imamo na eni strani skupino, ki delo obvlada, in na drugi strani skupino, v kateri so vajenci. Novejše raziskave niso omejene na položaj vajencev (vstopajočih, ki prevzemajo že uveljavljene načine prakse).

Izhodiščne raziskave so bile antropološko obarvane in so uporabljale etnografske metode. Skupnosti prakse so bile v delih E. Wengerja in J. Lave opredeljene kot neformalne skupine ljudi, ki po »naravni poti« (natural way) razvijajo znanje, povezano z njihovo skupno prakso (Lave, Wenger, 1991). Nato skupnosti prakse bolj natančno opredelijo kot neformalne skupine, kjer skupaj rešujejo probleme, si prenašajo informacije, se pogovarjajo o svoji praksi, so drug drugemu mentorji, načrtujejo dejavnosti, razvijajo orodja in miselne načine, ki postajajo del skupnega znanja (common knowledge of the community) (Wenger, $2006: 4$ ).

Kasneje pa so se začele intenzivne raziskave v sklopu delovanja služb za razvoj človeških 
virov (human resource development). Ena vidnejših raziskovalk je Charlotte Linde, ki zdaj raziskuje v okviru NASE. Raziskovalci iščejo načine, kako bi spodbujali naključno učenje (učenje, ki je naravni spremljevalec delovanja) in razvijali možnosti za profesionalni razvoj (na specifičnih področjih), zato so koncept skupnosti prakse v okviru razvoja človeških virov uporabili za namerno spodbujanje in organiziranje učenja ter za razvoj metod učenja na delovnem mestu. Uporabljajo ga kot izhodišče za pripravo kompleksnega učnega okolja v povezavi z delovnim okoljem. Model skupnosti prakse se pojavlja tudi kot model učenja pri medgeneracijskem mentorstvu. Slednje sta raziskovala Cumming-Potvin in MacCallum (2010), manj pa je razširjen pri raziskavah s področja učenja $\mathrm{v}$ lokalnih skupnostih in družinah.

Najbolj pogosto navajana empirična študija v zgodovini razvoja skupnosti prakse (poleg prve antropološke študije J. Lave) je etnografska raziskava Juliena Orra (Orr, 1996, 1990) v podjetju Xerox, kjer je raziskoval delovne prakse pri popravljanju fotokopirnih strojev. Ugotovil je, da imajo priročniki, s katerimi delavce usposabljajo za delo, omejeno vlogo, saj se dogajajo nepredvidljive situacije in zapleti, za katere se delavci ne morejo vnaprej usposobiti. Praksa popravljanja strojev, pa četudi gre za zelo ozko in tehnično dokaj detajlno predvidljivo področje - morda je bil tudi zato rezultat raziskave bolj zanimiv - sega »prek« priročnikov. Zahteva namreč tudi kompetence, ki jih ni mogoče predvideti. Vsak popravljalec (tehnik) se mora znajti $\mathrm{v}$ specifičnih situacijah, ki zahtevajo inovativen pristop. Izstopajo tiste situacije, ko mora tehnik tematizirati nov problem in ga znati rešiti na nov način. Poleg tega je pomembno tudi to, da tehniki opravijo svoje delo tako, da se pri strankah razvije zaupanje $\mathrm{v}$ njihovo storitev. Ne gre le za vzdrževanje fotokopirnih strojev, ampak tudi za socialne povezave. Tako nastaja novo znanje $\mathrm{v}$ okolju in se nato razvija lokalna raba tega znanja (ki je specifična). Spoznanja se prenašajo z neformalnim komuniciranjem v t. i. intersticiju časa, npr. ko pijejo kavo ali ko čakajo na dele v skladišču. Tu imamo znanje, ki v praksi nastaja in se $\mathrm{v}$ prakso prenaša. Ugotovil je, da je zelo pomemben vmesni čas in kaj se dogaja v tem času. Slednje je odvisno od medsebojnih odnosov, medsebojnega zaupanja, spoštovanja profesionalnosti, organizacijske solidarnosti. Če se vrnemo $h$ konceptu tihega znanja, lahko sklenemo, da ne gre le za tehnične spretnosti, marveč tudi za jezikovne, socialne, emocionalne zmožnosti, ki opredeljujejo pretok znanja.

\section{ZNAČILNOSTI SKUPNOSTI PRAKSE}

Skupnost prakse je neformalna skupina ljudi, ki ima skupno področje delovanja, skupen problem in skupno področje znanja.

Skupnost prakse je skupina posameznikov, ki so oblikovali mrežo odnosov in opredelili modalitete, po katerih delajo (work) in delujejo (activity), vzpostavljajo odnose (pravila interakcije) in interpretirajo dogodke. Člani skupnosti prakse so med seboj čustveno povezani, med člani so vzpostavljeni odnosi, tako da vedo, kdo je znotraj in kdo je zunaj. To pomeni, da gojijo občutek pripadnosti in skupno identiteto, čeprav je skupina neformalna.

Za skupnost prakse je značilno, da se ljudje povezujejo ob »rečeh, ki jih je treba narediti«, to je ob skupnih projektih, za katere imajo na voljo eksplicitno in tiho znanje. Imajo torej skupno prakso (nekaj producirajo) in skupno znanje, ob katerem vzgojijo podoben slog mišljenja o svojem produciranju in gradijo skupne pomene. Sčasoma razvijejo praktični čut, 
ki omogoča improviziranje in jih ločuje od drugih skupnosti prakse.

Akterji se spontano zberejo v praksah, v katerih se razvijata solidarnost in specifičen diskurz. To so skupine, ki nastanejo ob skupnih problemih in trajajo, dokler obstajajo skupni interesi in dokler se reproducira skupnostna (povezovalna) energija.

Wenger (1998) ter Wenger in drugi (2002) so skupnosti prakse opredelili z več značilnostmi.

Prva značilnost skupnosti prakse je povezanost med delom oz. delovanjem, učenjem in inoviranjem. To se dogaja v procesu uresničevanja idej, osrednji proces v vsaki praksi je spreminjanje abstraktnega $\mathrm{v}$ konkretno, idejam damo obliko, denimo kot dokumenti, procesi, izdelki, simboli. Učenje v skupnostih prakse je priložnostno, vendar pa ga z razvojem menedžmenta znanja organizatorji kanalizirajo v oblike, da bi bilo čim bolj učinkovito. Razvijajo se didaktične strategije, saj so skupnosti prakse model, ki daje možnost, da v izbranem okolju proučimo strategije učenja, kot so naredili že v več raziskavah (prim. Akkerman, Petter, Laat, 2008), in nato oblikujemo pristope za:

(a) vrednotenje učenja v konkretnih situacijah, pri določenih dejavnostih (pri nekem delu ali v nekem kraju); to lahko vodi v evalvacije in priznavanje kompetenc;

(b) spodbujanje ustvarjalnosti in refleksije ob delu in tako spodbujanje spreminjanja odnosov, ljudi, produktov.

Druga značilnost je diskrepanca med načrtovanim delom in delom, ki je potem opravljeno. Načrtovana dinamika in vsebine se razlikujejo od resnične dinamike $\mathrm{v}$ praksi, ki se uresniči. V izobraževalni praksi so najbolj znane razlike med načrtovanim in uresničenim kurikulumom. Priznati moramo, da v praksi nimamo le predvidenega dela, temveč se to vmes tudi spreminja. Remodulira se tudi kodificirano znanje in ne le tiho znanje. Ta razlika med načrtovanim in uresničenim omogoča ustvarjalnost in veliko situacijskega učenja. Lahko pa je vir zmede, če ljudje niso ustvarjalni in pripravljeni na učenje.

Tretji element, pomemben za našo refleksijo, je artikulacija izkušenj. Pri artikuliranju izkustvenih in odnosnih dinamik situacijskega učenja so izjemnega pomena improvizacija, sodelovanje in naracija. Improvizacija se nanaša na izkušnjo, ki zapolni razliko med načrtovanim delom in konkretno realnostjo, kot smo zapisali zgoraj. Načrtovane so predvidljive dejavnosti, ki so varne, stabilne, vendar rutine niso vedno dovolj. Akterji si izmislijo nove rešitve, ko identificirajo probleme. Bistven element pri artikulaciji izkušenj je sodelovanje in pripovedovanje. Nastajajo skupnosti s svojim lastnim slogom pri delu in tudi slogom refleksije o problemih. S sodelovanjem nastaja bazen skupnega znanja, ki se prenaša z naracijo. Naracija vključuje komunikacijske prakse $\mathrm{v}$ neformalnih časih in prostorih, ko si akterji povedo izkušnje. Pripoved je intenzivno sredstvo za razumevanje dogodkov oz. za razumevanje različnih vidikov subjektivne resničnosti, ker sledimo sekvencam, motivom, vzrokom in posledicam. Če si ljudje ne zaupajo med seboj, si ne bodo pripovedovali izkušenj. Povezava med improvizacijo, sodelovanjem in naracijo kaže na situacijskost znanja, kar odpira naslednji problem. To je vprašanje, kako oblikovati modalitete, da bi se inovativno znanje reproduciralo tudi $\mathrm{v}$ drugih okoljih.

Že ob prvih raziskavah, v katerih je bil poudarek na vstopanju novincev $\mathrm{v}$ prakso, so oblikovali konstrukt legitimne in periferne participacije, ki opisuje procese socializacije na delu. Znano je uvajanje pripravnikov, ki so 
postopoma vpeljani v delo, postopoma sprejemajo naloge. Ob tem se razvijajo bolj ali manj intenzivni odnosi z drugimi subjekti.

Periferna in legitimna participacija pomeni, da novinec:

- sprejme dejavno vlogo, tako da najprej opravlja preprostejša dela in nato vedno bolj kompleksna, kar ga vodi v odnose $\mathrm{s}$ širšim krogom ljudi, s tem se oblikujeta njegova identiteta in pomen;

- $\quad$ je s soglasjem sprejet v skupnost, o njegovi prisotnosti se ne razpravlja, strukture in mehanizmi moči ga sprejmejo, to pomeni, da je njegov vstop socialno legitimen;

- participira v delu tako, da prehaja od perifernih pozicij/vlog k bolj kompleksnim, v skupnosti prakse ima najprej periferno vlogo;

- $\quad$ v stik pride z diskurzom, prek katerega spoznava in se uči, kako delati, katero vedenje je sprejemljivo, kakšna je struktura moči.

Ne glede na to, kako je uvajanje novincev formalizirano, se vedno ponovijo zgornje faze. Novinec se sreča s »situacijskim kurikulumom «, ko učenje poteka z opazovanjem, opravljanjem enostavnih del in nato bolj zapletenih. Situacijski kurikulum zajame vse faze socializacije v organizaciji, ko poteka situacijsko učenje. To je učenje, značilno za tisti prostor in čas. Ko se bo posameznik prezaposlil, se bo spet srečal z novim situacijskim kurikulumom, z novo situacijo legitimne in periferne participacije.

\section{PRIMERJAVA SKUPNOSTI PRAKSE IN AKCIJSKEGA UČENJA}

Naša izhodiščna teza je bila, da učenje v skupnosti prakse artikulira možnosti za razvoj didaktičnih strategij, ki spodbujajo in usmerjajo situacijsko učenje. V nadaljevanju bomo predstavili primerjavo med skupnostjo prakse in akcijskim učenjem. Pri obeh sta v ospredje postavljena praktični način spoznavanja in izkušnja kot objekt refleksije.

Za oba modela je značilno, da vključujeta skupino ljudi, ki se uči, da bi izboljšala svoje delovanje, večinoma povezano s profesionalno prakso. Vključeni imajo skupen interes in si prenašajo znanje med seboj. Med obema pojavoma pa obstajajo tudi razlike. Skupnosti prakse so neformalne skupine, ki nastanejo kot spontane povezave, tako poudarja Wenger. Akcijsko učenje pa je model učenja, vpeljanega na delovnem mestu, kjer so poti prenosa znanja in legitimiranja znanja bolj jasne.

Akcijsko učenje je didaktična strategija, ki se je začela razvijati v času med obema vojnama, kronološko torej pred raziskovanjem skupnosti prakse. Nastajala je z opazovanjem prakse.

Začetnik modela je bil fizik R. Revans iz Velike Britanije, ki je opazoval delo in učenje med raziskovalci v laboratoriju (Revans, 1998). Po drugi svetovni vojni se je model intenzivno razvijal $\mathrm{v}$ okviru izobraževanja menedžerjev (O'Neil, Marsick, 2011). Akcijsko učenje je paradigma učenja, ki sloni na konceptu reševanja realnih problemov. Odvija se med spraševanjem in iskanjem rešitev med osebami, ki so vpletene $\mathrm{v}$ reševanje problema. Model se je v svojem razvoju oprl na teorijo transformativnega in projektnega učenja. Poudarek je na spreminjanju, ustvarjanju znanja.

Akcijsko učenje je opredeljeno kot socialni proces, ki vključuje zaposlene v neki organizaciji. Ti se združujejo v skupine, da bi premislili svojo prakso ob reševanju problemov in interpretirali izkušnje. Skupina, ki uporablja akcijsko učenje, se oblikuje kot projektna skupina $\mathrm{z}$ jasnimi in konkretnimi cilji. Učenje je $\mathrm{v}$ tem modelu načrtna strategija, ki je vpeljana, da bi 
izboljšali prakso. Akcijsko učenje pogosto povezujemo z modelom akcijskega raziskovanja. Obe strategiji uporabljamo, ko se znajdemo pred nerutinskimi situacijami, ko ne obstajajo standardne rešitve. Akcijsko učenje (action learning) se povezuje $\mathrm{z}$ akcijskim raziskovanjem (action research) v modelu ALAR.

V obeh modelih - skupnosti prakse in akcijskem učenju - gre za učenje, ki se dogaja v praksi. To pomeni, da učenje poteka s participacijo $\mathrm{v}$ praksi in spreminjanjem prakse. Učenje ni dekontekstualizirano. $\mathrm{V}$ obeh modelih učenje razumemo kot sociokulturni fenomen. Bistvena razlika je $\mathrm{v}$ tem, da lahko skupnost prakse nastane iz formalne skupine, če se razvije občutek pripadanja, skupinska identiteta. Ne moremo pa skupnosti prakse ustanoviti kot formalno skupino. Wenger temu celo nasprotuje. Meni, da bi bil to menedžerski paradoks (prim. Wenger, Snyder, 2002). V nadaljevanju na kratko predstavljamo razlike med skupnostjo prakse in akcijskim učenjem, in sicer glede na izbrane kategorije: znanje in legitimiranje znanja, skupnost, praksa.

\section{Polje znanja (domena)}

\section{Skupnost prakse}

Področje védenja je socialno konstruirano v skupnosti in ga v skupnosti tudi nenehno prenavljajo, to vključuje stalno pogajanje ali dogovarjanje o pomenih.

Participacija se gradi prek izkušnje delovanja v skupnosti, ki je dolgotrajnejše kot pri akcijskem učenju.

Področje in skupno znanje je identifikacijski element, ki združuje skupnost.

\section{Akcijsko učenje}

Participacija se gradi ob objektu učenja, to je ob reševanju problema.

\section{Skupnost}

\section{Skupnost prakse}

Skupnost je utemeljena na razmeroma (dolgo)trajnih interakcijah.

Je prostovoljna, naključna, sestavljajo jo osebe, ki imajo občutek pripadanja, skupno identiteto, občutek vzajemnosti, opredeljujeta jih skupno tiho znanje in vsakdanja praksa, prek katere se identitetno formirajo (postajajo).

Kompetence se razvijejo v skupnosti in se kažejo kot praktični čut in habitus, po katerem se ločijo od drugih skupnosti.

\section{Akcijsko učenje}

Ni nujno, da je skupina dolgotrajna. Lahko je vzpostavljena le za reševanje izbranega problema.

Omejena je na osebe, ki se srečajo v specifični situaciji ob določeni nalogi.

Ni nujno (a je zaželeno), da se bodo razvili občutki pripadnosti, člane skupine povezujejo okoliščine in projekt (cilji projekta). Ali se bo razvil občutek pripadnosti, je odvisno predvsem od načina vodenja akcijskega učenja. Pri akcijskem učenju imamo navadno vodjo skupine, medtem ko skupnost prakse nima vodje.

\section{Praksa}

\section{Skupnost prakse}

Praksa je kolektivni produkt, socialno določen način delovanja, slog mišljenja in vedenja, po katerih se ravnajo člani skupnosti. Praksa spodbuja razvoj praktičnega čuta. 


\section{Akcijsko učenje}

Praksa je vodena izkušnja (v nekaterih oblikah je vključen mentor) ali pa samostojno učenje.

Razlikuje se glede na kontekst in modele izobraževanja (oz. formiranja).

Ker gre za razmeroma kratkotrajno druženje (v primerjavi s skupnostjo prakse), se ne razvije praktični čut niti »modus operandi «, ki bi bil značilen za skupino.

\section{Legitimiranje znanja}

\section{Skupnost prakse}

Legitimiranje znanja je utemeljeno na medsebojnem priznavanju (npr. med skupnostjo prakse in menedžmentom podjetja), na nenehnem razvijanju skupnih pomenov in dogovarjanju o delovanju ter avtonomiji skupnosti prakse glede na cilje podjetja, če gre za skupnosti prakse v podjetju.

Sicer je legitimiranje znanja povezano z medsebojnim priznavanjem članov in učinkovitostjo delovanja.

\section{Akcijsko učenje}

Znanje legitimira organizacija oz. podjetje. Legitimiranje znanja je intenzivnejše, če financerji ali sponzorji pridobijo boljše rezultate.

Če se držimo opredelitve skupnosti prakse po Wengerju, lahko ugotovimo, da skupnost prakse kot spontana skupina lahko preide $\mathrm{v}$ akcijsko učenje ali pa uporabi akcijsko učenje za svoje delovanje. Skupine, ki nastanejo z organizacijo ob akcijskem učenju, lahko po končanem akcijskem učenju razpadejo ali pa prerastejo v skupnosti prakse. Pot med obema oblikama je odprta.

Oba modela se v sodobni praksi uresničujeta $\mathrm{v}$ povezavi z zamislijo refleksivnega prakti- ka in učeče se organizacije ter razvijata nove preplete, ki kažejo na nenehno razvijanje modelov. Ob uporabi enega ali drugega modela pa se kot pomembni pokažejo naslednji skupni elementi:

$\mathrm{Na}$ ravni konstrukcije produkta (inovacija, reševanje problema) je pomembno, da člani skupine občutijo zavzetost. Produkt, ki ga razvijajo, mora biti za vse člane cilj, ki prinaša zadovoljstvo. Pomembne so čustvene komponente delovanja. Če so ljudje zavzeti za delovanje, dobijo nagrado v obliki psihičnega zadovoljstva ter stanja optimalnega doživetja in zavzetosti ali flow, kot ga imenuje Csikszentmihalyi (2008). Če bi se vrnili k opredelitvi prakse po MacIntyru, pa je zavzetost povezana z občutenjem notranjega dobrega.

$\mathrm{Na}$ ravni znanja sicer obstaja razlika med skupnostjo prakse, kjer je skupina oblikovala skupno znanje, in skupino pri akcijskem učenju, kjer so lahko združeni različni strokovnjaki. Pri obojih pa je pomembno, da prihaja do pretoka znanja. Pri razvijanju novih produktov se uveljavljajo skupine, ki vključujejo različna znanja, ki prinašajo pluralnost kontekstov in možnost za izmenjavo različnih pogledov (po načelih transdisciplinarnosti). Če je v skupini vzpostavljeno zaupanje, je omogočen hiter pretok znanja. Poleg zavzetosti je torej pomembno medsebojno zaupanje.

Skupno delovanje še ni jamstvo, da se bo razvila tudi refleksija o praksi. Nasprotno. Lahko so skupine v skupnosti prakse tako tesno povezane, da ne nastane refleksija o praksi, temveč ponavljajo ustaljene rutine in skupinsko mišljenje, ki le krepi dokso. Refleksija terja odmor, postanek v delovanju, vpeljavo evalvacije in možnost za soočenje $\mathrm{z}$ napakami. To nakazuje na potrebo po dovolj vmesnega časa, ki se je pri raziskavah skupnosti prakse izkazal kot pomemben za prenos znanja 
(Orr, 1996; Linde, 2009), v obeh modelih pa je vmesni čas pomemben tudi za refleksijo in odmik od ustaljenih rutin.

V praksi se kaže tudi pomen fizične bližine, čeprav se v sodobnosti krepijo virtualne skupnosti. Telesna bližina omogoči vse vrste komunikacije. Verbalna in neverbalna komunikacija je v obeh modelih temeljnega pomena.
Skupno delovanje omogoči razvoj zaupanja, hkrati pa tudi pojav čustvenih napetosti in konfliktov, zato so $\mathrm{v}$ obeh primerih potrebna znanja s področja skupinske dinamike in učenja kot čustvenega procesa. Pri akcijskem učenju je to odvisno predvsem od znanja vodje skupine, pri skupnosti prakse pa od same skupinske dinamike ter socialne in čustvene inteligentnosti vključenih.

\section{SKLEPNE UGOTOVITVE}

Koncept skupnosti prakse je analitično orodje za opazovanje in interpretiranje učenja kot dela vsakdanjega življenja. Organizirano izobraževanje načrtno uvaja spremembo, da bi se posameznik učil. Pri situacijskem učenju nastaja učenje kot posledica sprememb, ki niso vpeljane namerno, torej zato, da bi se učili. V našem okolju je dobro razvito tisto učenje, ki je v funkciji usposabljanja za neko dejavnost. Ta model označujeta transmisija dekontekstualiziranega znanja in poučevanje, zato je najbolj pogost $\mathrm{v}$ formalnih sistemih izobraževanja. Druga vrsta učenja, ki je tudi razmeroma dobro razvila svoje strategije, je učenje za spremembe v organizacijah. Ta model izobraževanja je načrtovan zato, da bi spodbudil organizacijski razvoj, dal podporo za spreminjanje delovanja. Tretji model izobraževanja pa se osredotoča na razvoj, ki je nepredvidljiv. Izobraževanje presega potrebe nekega konkretnega delovnega mesta $\mathrm{v}$ nekem konkretnem okolju. Cilj tega tipa izobraževanja je avtentičen razvoj posameznika in skupine, dolgoročni cilj je formiranje identitete posameznika (identizacija) in skupine ob ustvarjalnem delovanju. Situacijsko učenje je vključeno v vse tri modele, a se kot posebno pomembno kaže v tretjem modelu, ki poudarja ustvarjalnost.

V sodobnosti se razvija raziskovanje učenja kot procesa spreminjanja v-svetu-kjer-živimo. Življenjski svet in vsakdanja praksa sta okolje in sredstvo učenja v odraslosti. To je področje, s katerim se ukvarja andragogika vsakdanjega življenja. Sodobne teorije o učenju vključujejo delovanje, mišljenje, čutenje in čustvovanje, vrednotenje in tudi kolektivne kulturnohistorične oblike prakse. V obeh modelih, ki smo ju primerjalno predstavili, je znanje kompleksno, nastaja s konstrukcijo in ni nevtralno, temveč je kulturno pogojeno. Predstavljena načina učenja se razlikujeta $\mathrm{v}$ stopnji organiziranosti, oba pa učenje povezujeta $\mathrm{z}$ delovanjem v življenjskem svetu.

Skupnosti prakse so skupine, ki delujejo dlje časa in tudi potrebujejo več časa za svoj razvoj, zato so v okolju, ki je usmerjeno na hitre učinke, zahtevnejša oblika in je v podjetjih težje doseči njih uresničevanje - tudi zaradi potrebe po socialnih in emocionalnih kompetencah članov. Kot prostor za prenašanje in ustvarjanje znanja so bolj zaželene v okoljih, kjer je omogočena refleksija in kjer je sprejeta tudi čustvena komponenta učenja kot pot za graditev skupnosti.

$\mathrm{Z}$ vidika razvoja teorije in prakse učenja odraslih so skupnosti prakse pomemben model, ker presegajo dualizem med humanističnim poudarjanjem samostojnosti (avtonomnosti) subjekta in samostojnega učenja ter socialnimi 
teorijami, ki postavljajo v ospredje družbeno determiniranost subjekta. Nobeden od teh dualistično postavljenih polov sam zase ni dovolj učinkovita interpretativna shema. Prvi se zdi nekoliko naiven, ko zanemari moč socialnih struktur, drugi se zdi pesimističen s prikazovanjem popolne uklenjenosti posameznika v strukturo. Model skupnosti prakse ponudi možnost, da se ognemo binarnim opozicijam pri proučevanju učenja, ko združi posameznika in socialno okolje v medsebojno prepleten kompleks diskurzivnih in somatskih praks.

Situacijsko učenje in teoretski okvir prakse je le eden od interpretacijskih modelov, ki dopolnjuje druge teorije o učenju. V praksi je dobrodošel, ker lahko razvijamo učenje na delu in v lokalnem okolju. V andragoški teoriji pa je dobrodošel, ker razširimo polje raziskovanja na učenje v vsakdanjem življenju.

\section{LITERATURA}

Akkerman, S., Petter, C., Laat, M. (2008). »Organising communities-of-practice: facilitating emergence «. Journal of Workplace Learning, 20(5-6): 383-399.

Bourdieu, P. (2002). Praktični čut. Ljubljana: Studia humanitatis.

Engeström, Y. (2010). »Expansive learning: toward an activity theoretical reconceptualization «. V: Illeris (ur.). Contemporary Theories of Learning. London.

Csikszentmihalyi, M. (2008). Flow: The Psychology of Optimal Experience. New York: HarperColins Publ.

Cumming-Potvin, W. M., MacCallum, J. A. (2010). »Intergenerational Practice: Mentoring and Social Capital for Twenty-first Century Communities of Practice«. McGill Journal of Education, 45 (2): 305-323. Dostopno na http://id.erudit.org/ iderudit/045610ar (pridobljeno 22. 6. 2011).

Gherardi, S., Nicolini, D. (2004). Apprendimento e conoscenza nelle organizazioni. Rim: Carocci.
Daniels, H., Edwards, A., Engeström, Y., Gallagher, T., Ludvigsen, S. (ur.) (2009). Activity Theory in Practice. London: Routledge.

Hager, P., Halliday, J. (2009). Recovering Informal Learning. Dordrecht: Springer.

Illeris, K. (ur.). (2010). Contemporary Theories of learning. London, New York: Routledge.

Kimble, K., Hildreth, P. (2008). Communities of Practice: Creating Learning Environments for Educators. Information Age Publishing. Dostopno na www.chris-kimble.com/CLEE/ToC.html (pridobljeno 12. 3. 2012).

Knorr-Cetina, K. (1999). Epistemic Cultures. How Science Make Knowledge. Cambridge: Harvard University Press.

Lave, J., Wenger, E. (1991). Situated Learning: Legitimate Peripheral Participation. Cambridge: Cambridge University Press.

Linde, C. (2009). Working the Past. Narrative and Institutional Memory. Oxford: Oxford University Press.

MacIntyre, A. (1981) After Virtue. London: Duckworth.

Nonaka, I., Takeuchi, H. (1995). The Knowledge Creating Company. New York, Oxford: Oxford University Press.

O’Neil, J., Marsick, V. J. (2011). Understanding Action Learning. New York: Amacom.

Orr, J. (1990). Sharing Knowledge, Celebrating Identities, War stories and Communities memory in a Service Culture. Ithaca: Cornell University Press.

Orr, J. (1996). Talking about Machines: An Ethnography of a Modern Job. Ithaca: Cornell University Press.

Polanyi, M., Sen, A. (2009). The Tacit Dimension. Chicago, London: Chicago University Press.

Postill, J. (2010). »Introduction: Theorising media and practice «. V: Bräuchler, Postill, (ur.), Theorising media and practice. Oxford, New York.

Revans, R. (1998). ABC of Action learning. London: Lemos \& Crane.

Reckwitz, A. (2002). »Toward a Theory of Social Practices «. European Journal of Social Theory, 5(2): $243-263$. 
Wenger, E. (2006). Comunit di pratica. Apprendimento, significato e identit . Milano: Raffaello Cortina Editore.

Wenger, E. (2010). »A social theory of learning «. V: Illeris (ur.) Contemporary theories of learning. London, New York.

Wenger, E., McDermott, R., Snyder, W., (2002). Cultivating Communities of Practice: A Guide to Managing Knowledge. Boston: Harvard Business School Press.

Wilson, A. (2010). Knowledge Power. London, New York: Routledge. 